\title{
PUBLIC POLICY AND ETHNICITY: THE POLITICS OF ETHNIC BOUNDARY MAKING
}

Edited by Elizabeth Rata and Roger Openshaw

Basingstoke, Hampshire and New York, Palgrave Macmillan, 2006. 222 pp, ISBN 0-230-00338-9

\section{Reviewed by \\ Grant Duncan}

It's not unusual to find people who disavow allegiance to the 'imagined community' known as 'the nation-state' in favour of a declaration of belonging to some other 'imagined community' - say, a global religious community, or a local tribal kin-group. This may partly be prompted by a sense of exclusion or injustice arising from the application of public policy within the nationstate. This is not a new phenomenon, but is apparently fuelled by globalization. Often such alienation and alternative identification are relatively harmless - sometimes not. But the state is obliged to respond to such issues, and must at least attempt to make public services equally accessible for people of diverse cultural backgrounds.

The contention of the editors of the present volume is that policies of multiculturalism - as well as, in New Zealand, biculturalism - have only made matters worse by demarcating ethnic boundaries. Reconstructed notions of cultural authenticity, difference and tradition are applied to create artificial ethnic distinctions, which then lay the ground for inequity and conflict. While they accept that individuals can and do identify themselves with an ethnic group, their critique is on the politicisation of that ethnic identity whereby ethnicity becomes an institutionalised category recognised in government policies' (p. 3).

This is more than just a shade of Don Brash's 2004 Orewa speech. It is rather like an extended intellectual ovation for that speech. And hence this text engages in its own form of politicization. It attacks a 'liberal left' that has pro- 
moted 'culturalism', but the editors' introduction does not clearly define who the liberal left's authors are, or their key texts, and there is not enough serious examination of their ideas. Openshaw, in his own chapter, does document the pedigree of the doctrine of biculturalism, but his narrative ends in the mid198 os, and many relevant social scientists are left unscathed. In other chapters, Mason Durie is a target of criticism, but, overall, this text does not properly identify and examine the cultural theories that it seeks to oppose.

Now, I accept that biculturalism and multiculturalism have their problems. Official statistics on ethnicity are fraught with problems in defining groups and thus potentially creating artificial categorizations that fail to reflect complex social realities. Policies on cultural sensitivity have sometimes led to instances of conformism and indeed bullying, and, for some people, a heightened sense of ethnic identity and historical grievance can lead to a rejection of the principles of universal human rights and individualism implicit in the constitutions of liberal-democratic states. For reasons such as these, policies that attempt to avert racial discrimination or to apply special measures to disadvantaged minorities must be open to critical reappraisal. As Dr Brash revealed, the perception of favoritism to a minority can create deep feelings of resentment, and the political effects of such resentment do require an appropriate response.

On the other hand, the international framework of universal human rights is in itself a product of a culturally specific set of political precepts. The domestic legal system of New Zealand is of British origin, and, in the mid-nineteenth century, it was put into force by a legislature that initially had no representation from the indigenous population. This is not to say that the UN's human rights covenants or British law are not, in their own ways, reasonable. It is just to acknowledge something that the present text overlooks: that the 'universalism' that the editors declare in favour of has had to be imposed by hegemonic means, and that the sense of cultural exclusion that may result could require some compensatory response, if only to maintain the legitimacy of the law and some semblance of social cohesion. To this effect, international human rights covenants allow for the individual's right to freedom of cultural self-expression and belonging, and governments have an obligation to put this into practice, including policies that may protect, or even promote, minority-group interests. It is at this point that the contentions of the editors of this text collapse in upon themselves.

At a practical level, the book offers little for the reader of public policy, an applied discipline that needs ideas about, for example, how to prevent minority indigenous languages from dying out, how to make public services accessible 
to refugees, how to discourage hatred and violence against Jews and Muslims, or how to make it safe for minorities to practice their religious faiths. Hence, although the text uses the term 'public policy' in its title, it is of little use to students of public policy, as it does little more than criticize policies that have sought to be inclusive of diverse cultures and to recognize the universal right to cultural and religious self-expression. It lacks constructive ideas about how to negotiate the tricky terrain of inter-ethnic politics.

For example, Elizabeth Rata objects to the way in which the politics of indigeneity and Treaty settlements result in the creation of tribal elites that are engaged in capitalist accumulation, leaving others of their kin supposedly in poverty.

Such ethnic politics has serious consequences for the ongoing structural cohesion of the nation-state itself. It also leads to the effective disempowerment of the majority of the very people that ethnic politics was ostensibly supposed to assist (p. 53).

This is a sophisticated way of saying things that one might hear on talk-back shows: 'Treaty settlements only make a few brown guys rich, and leave ordinary Maori locked out of the benefits.' Still, they are serious claims - but Rata does not provide an alternative remedy for unjust land acquisitions and failures to acknowledge Maori cultural aspirations. Should we just ignore these matters? If so, what would the consequences be? And, what is so wrong with Maori organizations engaging in capitalist enterprises, given the global capitalist world they exist in? Does she expect iwi organizations to practice a form of social democracy that central government abandoned in 1984? It's not at all clear.

Martin Devlin challenges notions about a distinctive 'Maori business' and 'Maori economy', and Christopher Tremewan pulls off a trenchant critique of the racialised constitution implemented by the Anglican Church. Reinvented and institutionalized notions of ethnicity, especially when blended with European social or religious constructs, do often sit uncomfortably, and it may be difficult for a sceptical on-looker to question them for fear of being accused of racism. They often rely on essentialised ideas about culture and identity that may not withstand careful theoretical critique. Nonetheless, these two contributions seem less than generous, in that they do not acknowledge possible benefits for businesses or for church groups in developing distinctive cultural voices and identities, based on diverse values and practices, and that this may require, at least for a period of time, structural or policy changes. 
Paul Callister gives a well-reasoned appraisal of the difficulties inherent in the measurement of ethnicity in populations and the policy implications of this. In spite of these difficulties, and the potential to 'create negative stereotypes' through ethnic categorisation, he agrees that it is useful for policy-makers to know something about the inter-ethnic distribution of the factors of social well-being. And, although the reader may initially have expected that this book's authors would be opposed to 'special measures' for the achievement of equality by disadvantaged ethnic groups, at least one of them (John A. Clark) does accept that, although equality must be the basic principle of social justice, there may be occasions when 'preferential treatment' is needed.

Roy Nash takes up the debate about educational achievement and the disparity between Maori and Pakeha, particularly around the finding that family resources and practices may be more significant factors in outcome than ethnic-group membership. This debate is interesting in itself, but the chapter does read like one more shot in an ongoing domestic feud among New Zealand educationalists. And it is this 'local' quality of most of this volume that belies its apparent pretension to be an international text, published by an international publishing house, with presumably an international audience in mind. So much of the material is about New Zealand that one wonders how successful the volume will be in that market. The editors argue that New Zealand is once again distinguishing itself as an experimental case when it comes to 'culturalist' policies, and hence that the rest of world will want to read about it. But I find this appeal to the 'social laboratory' thesis unconvincing. Each country faces unique local inter-ethnic political tensions, and hence one country's experience cannot really be generalized internationally.

This book is likely to be seen as a provocative salvo in the 'culture wars' debate, especially for New Zealanders. I support the idea of critical self-reflection on this highly political subject. This text, however, has an unhidden agenda - reflected in its use of the term 'ethnic boundary making' in the subtitle - which gives it theoretical coherence perhaps, but does make it rather one-sided. The editors especially, and most of the other contributors, are hostile to the use of ethnic categories in public policy, but they are not altogether helpful in reconstructing alternative approaches. Arguably, third-way politics has papered over socio-economic inequalities with a preference for analyses in terms of ethnic disparities, and there is no doubt that this has caused some heated debates here and overseas. I get the impression though that the present government has already responded to political resistance to the emphasis on ethnic targeting, and that the pendulum is now swinging back in public policy thinking on this question. 
However, the editors over-estimate the effect that official ethnicity statistics and policies of cultural sensitivity and diversity may actually have on 'streetlevel' cultural practices and identities. Their view of the State seems too monolithic and universalist. Instead, analyses of culture and politics should account for more complex and evolving streams of influences. Perhaps they could also relent a little and recognize that political self-assertion by Maori and Pasifika communities has also had huge benefits for New Zealand society. 